\title{
The Need of an Integrated Framework for the Implementation of Blended Problem-Based Learning
}

\author{
Mohd Mokhzani Ibrahim ${ }^{1}$, Mohammad Yusof Arshad ${ }^{1} \&$ Mohd Shafie Rosli $^{1}$ \\ ${ }^{1}$ Faculty of Education, Universiti Teknologi Malaysia, Malaysia \\ Correspondence: Mohammad Yusof Arshad, Faculty of Education, UTM, Johor, Malaysia. Tel: 60-12-734-2065. \\ E-mail: fosuyars@yahoo.com
}

Received: November 4, 2014

Accepted: March 13, 2015 Online Published: June 28, 2015

doi:10.5539/ies.v8n13p33

URL: http://dx.doi.org/10.5539/ies.v8n13p33

\begin{abstract}
Since the performances of Malaysian students in Programme for International Student Assessment (PISA) and Trends in Mathematics and Science Study (TIMSS) are found to be lower compared to other participating countries worldwide, the importance of cultivating higher order thinking skills (HOTS) has been highlighted in the National Education Blueprint. The shift from conventional to blended learning, with the integration of face-to-face and online learning offers promising opportunities in realizing the aspirations of the National Education Blueprint. The current study is aimed to propose an integrated framework of blended problem-based learning (blended PBL) in promoting HOTS among Malaysian students. This study employed comparison constant analysis in understanding the possibilities of success of this approach in promoting HOTS.A total of 219 articles published from 2009 to 2014 were selected from: (a) SpringerLink, (b) ScienceDirect, and (c) Taylor \& Francis Online. The analyses of 30 articles were carried out based on criterion set for this study in developing the integrated blended PBL framework. In short, the findings of this current study exemplified that blended PBL is effective in promoting HOTS in Malaysian context.
\end{abstract}

Keywords: problem based learning, blended problem based learning, comparison constant analysis, integrated framework of blended problem based learning

\section{Introduction}

The performance of Malaysia in the Programme for International Student Assessment (PISA) 2012 which tested the students' abilities to apply scientific knowldege in real life situation, indicated that Malaysia was still in the lower quarter; ranked $53^{\text {th }}$ out of 65 countries (OECD, 2014). Similarly, in the Trends in Mathematics and Science Study (TIMSS) test, for Science subject, Malaysia's performance was still lower and ranked $30^{\text {th }}$ out of 40 participating countries (Martin et al., 2011). In this test, most questions assessed students' higher order thinking skills (HOTS), where $65 \%$ of the questions focussed on the thinking skills of applying and reasoning, and the remaining questions were focussing on lower order thinking skills of knowing (Martin et al., 2011).

The scenario above reflects that Malaysian students are still struggling in mastering HOTS. A study by Kiong, Heong, and Jailani (2010) manifested that the majority of the Malaysian secondary students were still considered as poor in HOTS. One of the influential factors is limited exposure and practice to HOTS in current teaching and learning settings in Malaysia (Ministry of Education Malaysia, 2012). The current practice of teaching applies conventional teaching approach, which is teacher-centred classroom (Nor-Fardia et al., 2012). The major drawback of this approach is students are not actively involved in knowledge construction process. Instead, they are exposed to rote-memorization and thus, are ineffective in cultivating higher order thinking skills (Tan, 2014).

\section{Background of Problem}

Resnick (1987) describes higher order thinking skills (HOTS) as skills that are complex, unstructured, multi disciplinary, reflective and deal with uncertainties. In addition, Lewis and Smith (1993) explicate that HOTS require active linking of new and prerequisite knowledge, which will be further improvised as a new set of knowledge in aiding problem solving skills. The aforementioned definitions are in line with Malaysian Examination Syndicate's assertion that HOTS require active reasoning and reflection of new and prerequisite knowledge in constructing relevant ideas and solutions to a problem (Malaysian Examination Syndicate, 2013).

Consequently, to develop students' HOTS, the teaching should focus on developing four higher order skills, 
which are applying, analyzing, evaluating and creating, as explained in Revised Bloom's Taxonomy (Krathwohl, 2002). These four domains require students to utilize their knowledge gained from the lower order thinking skills, which are remembering and understanding, in a different situation (Dwyer, Hogan, \& Stewart, 2014).

In realizing the aspiration to inculcate HOTS among Malaysian students, the Ministry of Education Malaysia has highlighted seven initiatives to reform education system, and one of them is the revamp in teaching pedagogy in schools (Ministry of Education Malaysia, 2012). To achieve this vision, an explicit teaching of HOTS (Avargil, Herscovitz, \& Dori, 2013; Barak \& Dori, 2009) with real-world experiences (Lam et al., 2013; Sellar \& Lingard, 2013 ) is found to be effective in improvising the mastery of HOTS among Malaysian students.

Problem-based learning (PBL) is a potential teaching and learning approach in improving students' HOTS. This approach employs real-world experiences with complex (Wirkala \& Kuhn, 2011) and unstructured convulsion (Brownell, 2004), which has infinite solutions to a specified problem (Hmelo-Silver, 2004). It is believed that this approach encourages HOTS such as critical thinking (Rissi, 2010). In a direct contrast, the conventional teaching is geared to rote-memorization and comprehension rather than prompting the discussed problem at the beginning of the lesson as in PBL (Hung, 2009). Very differently, in PBL context, the discussed problem will lead to a conflict in students' mind that later ignite inquiry among students.

In addition, PBL necessitates students to actively participate in collaborative and self-directed learning (Yew \& Schmidt, 2012) in seeking relevant information, and making responsible justification (Davies, de Graff, \& Kolmos, 2011) and reflection (Hmelo-Silver, 2004) based on their findings throughout the learning process. Through the completion of the task, students will be exposed to HOTS, which will later benefit their academic performance. However, a number of research has discovered that the implementation of PBL was not effective (Kirschner, Sweller, \& Clark, 2006; Koh et al., 2008) and at the same time unable to cultivate HOTS. The main contributing factor is the difficulties in implementing collaborative and self-directed learning during PBL process. As the result, students' academic performances will be affected and thus, HOTS will not be supremely achieved.

In implementing PBL in collaborative learning, students' active participation and involvemet with the emphasize of the concept of interdependence in learning (Yeung, 2010), accountability (Carbonell et al., 2013) and interpersonal skills (Davies et al., 2011) are highly required in solving a problem in the teaching and learning session. Nevertheless, a robust of literature has proven that collaborative learning in PBL is less effective (Dolmans et al., 2001; Hung, 2011). The contributing factors to this condition are different learning pace, uneven contribution and poor communication skills among students. In addition, the limitations in self-directed learning have resulted the students' inability to plan their learning strategy and evaluate the learning resources (Yew \& Schmidt, 2009).

Realizing the fact that PBL has a number of glitches in its implementation, the integration of technology, which is blended PBL, is potentially effective (Vardi \& Ciccarelli, 2008). In this manner, the blended PBL and hybrid learning interchangeably support each other, as both approaches integrate face-to-face learning and online learning (Delialioglu \& Yildirim, 2007) as the medium to cultivate HOTS (An, 2013). Most researchers similarly defined blended PBL as teaching approach that integrates face-to-face and online learning platform (Donnelly, 2013). In short, blended PBL is an enriched version of traditional PBL (face-to-face) with integration of online learning (Woltering et al., 2009).

Thus, the blended learning offers advantages in term of flexibility (Oliver \& Stallings, 2014; Taylor, Francis, \& Shannon, 2013), facilitation (Lau, Lam, \& Zhou, 2010) and communication skills (Kashefi, Zaleha, \& Yudariah, 2012). A study in the Malaysian context by Alias and Saleh (2007) has exemplified that blended or hybrid PBL is potentially effective in enhancing students' achievement and HOTS. Since the blended PBL offers practical alternatives to the traditional PBL,it is relevant to implement blended PBL in Malaysian classroom. To concern, there was limited framework that has been specifically developed for the implementation of blended PBL in fostering HOTS especially in the school context in the current body of literature.Realizing the potentials of blended PBL to improve the current PBL approach, it is relevant to purpose a framework that can address its opportunities and challenges in integrating it. It is believed that this framework will serve as a relevant reference point in developing HOTS in Malaysian classroom.

\section{Methods}

\subsection{Research Procedure}

The current study employs constant comparison analysis in developing blended PBL integrated framework. This approach offers advantages such as in: (a) understanding multiple meanings from data, (b) enabling researcher to analyse data systematically; and (c) assisting researches to construct the themes based on the retrieved data 
(Strauss \& Corbin, 1998). Figure 1 illustrated the steps being used in order to analyse the literature.

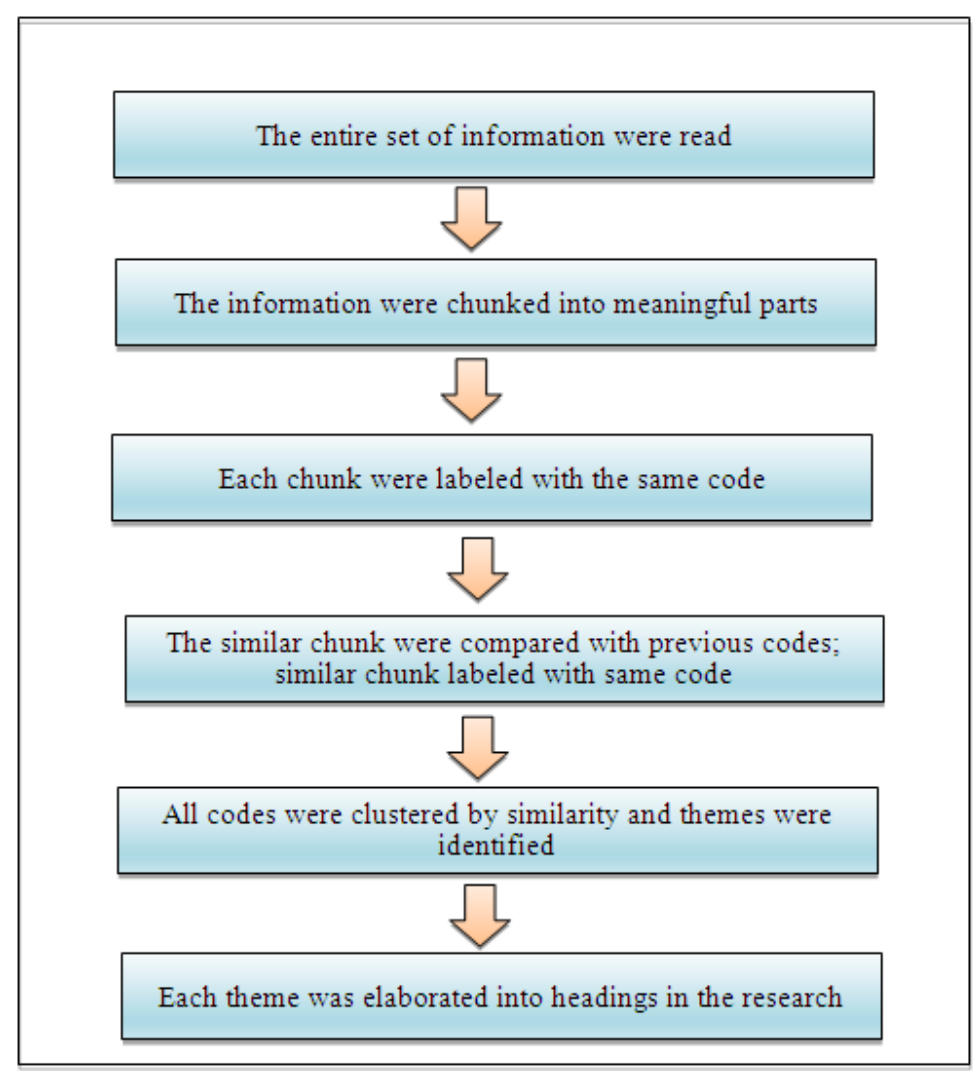

Figure 1. Adopted from Onwuegbuzie, Leech, and Collins (2012)

\subsection{Sampling Procedure}

The selected articles were systematically chosen from three online databases: (a) SpringerLink; (b) ScienceDirect; and (c) Taylor \& Francis Online. The keywords search used were "PBL Learning Process", "PBL online", "Blended Learning", "Blended PBL", "Higher order thinking skills". The search was also limited to empirical studies that were published in 2009 to 2014. By using these criterions, 291 articles were retrieved. Only 30 relevant articles, were reviewed based on the additional criterion such as: (a) the document presented the instructional intervention employed throughout the research exclude for review papers, (b) revealed the drawbacks of the PBL implementation; and (c) showed the benefits and the need of blended learning or blended PBL.

\section{Result}

In previous sections, it is established that blended PBL is potentially effective to overcome learning problems in both collaborative and self-directed learning settings. Thus, a specified framework is designed as in Figure 2.0 to represent learning process in blended PBL. Figure 2 illustrates the integration of technology in collaborative learning and self-directed learning through blended PBL in developing HOTS. Collaborative learning is conducted through online learning platform and face-to-face learning as discussed earlier. Besides, self-directed learning is directed via online learning platform with a major emphasis on facilitation in the term of scaffolding concept in enhancing students' ability at planning and evaluating learning resources. 


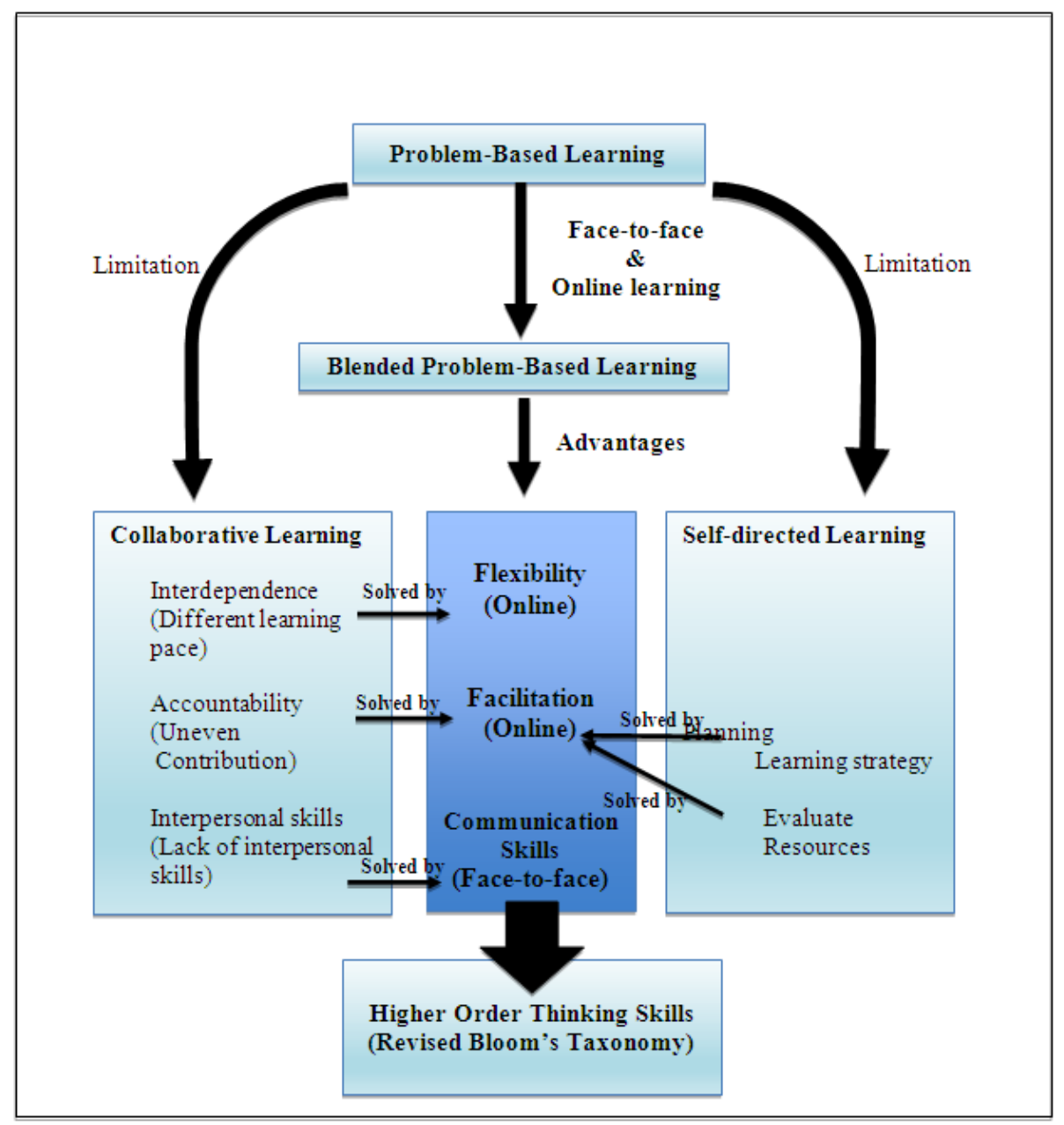

Figure 2. The integrated framework of blended problem-based learning

\section{Discussion}

\subsection{Collaborative Learning for Blended PBL}

Interdependence is one of the major concepts being emphasized in collaborative learning (Vijayaratnam, 2012). Students are mutually dependence on each other in their heterogeneous group to solve the given problem, through discussion. Typically, the different mastery level or learning pace among students is one of the major challenges in the heterogeneous group settings, and thus directly influences the development of HOTS (Ramli \& Zaharatul, 2011). Due to that, the tension might arise, as the advanced students tend to predominate the discussion of the assigned tasks. This parameter, render the weak students to be passive and tend to be the 'followers' of the activity. This condition is contradictory to the concept of active learning (Nargundkar, Samaddar, \& Mukhopadhyay, 2014) as proposed in PBL, and eventually hinders the acquisition of HOTS. As an alternative, blended PBL seems to be an ideal solution. Online learning in blended, PBL emphasizes on the concept of flexibility which allows ample 'space' and 'freedom' to participate in the learning process (Mccall, 2010; Qiu \& McDougall, 2013). Therefore, the students with poor mastery skills will have an ample time and space in understanding the content of the lesson. As the result, the development of HOTS is achievable. Vijayaratnam (2012) supported that active participation of students in learning encourages the mastery of multiple thinking skills, especially reflective thinking in learning.

On the other hand, collaborative learning process in PBL yields a problem in group's accountability in completing learning task. Shukor et al. (2014) stated that collaborative learning requires proper planning to ensure effective interaction during collaborative learning process. Uneven contribution might occur when the assigned tasks were not fully completed, limited contributions obtained during group discussion, and the difficulties to reach a consensus of the discussion (Hung, 2011). The relative contribution to the aforementioned 
problems is the large classroom size and limited facilitation during the lessons (Tan \& Muhammad, 2013). As the result, all students do not experience the experiential learning (Hmelo-Silver, 2004) as there might be several important learning steps skipped due to poor contribution of the group members. Therefore, the students will not achieve HOTS, which is emphasized in PBL.

Alternatively, blended PBL is practical to facilitate and monitor students' participations especially with the integration of log book as log recorder tool (Mohd et al., 2013). The logbook functions as a beneficial tool to help teachers to monitor students' progression from time to time. Indirectly, the concept of soft scaffolding can be applied, where teachers can take further actions to maximize the learning output during the PBL process. Thus, an overall and active participation is achievable, and the experiential learning can be implemented successfully.

Moreover, poor interpersonal skills might interfere the learning process in PBL classroom (Hung, 2011). The interpersonal skills are crucial to help students to actively participate in learning, and to achieve meaningful learning. Ineffective interpersonal skills are caused by lack of trust among group members, poor motivation to work together as a team and individualism among members of the group (Hung, 2011). As a solution, the asynchronous online discussion platform in blended PBL allows every member to actively participate regardless of his or her interpersonal skills and proficiency (Qiu \& McDougall, 2013). By using face-to-face interaction, both students and teacher are able to observe and understand the emotion level and react accordingly. Thus, the process of developing HOTS will be more efficient as the combination of online learning and face-to-face interaction synergize blended PBL in dealing with the differences in students' interpersonal skills.

\subsection{Using Self-Directed Learning for Blended Problem-Based Learning}

Blended PBL, which focuses on self-directed learning offers a potential alternative in developing HOTS.Choi, Lindquist and Song (2014) proposed a positive relationship between self-directed learning and mastery of HOTS Through the integration of self-directed learning, with or without facilitation(Maggi, 2004), students are required to analyze the learning expectations, set up learning objectives, carefully select learning sources and inputs, critically utilize appropriate learning strategies and indepently analyze their learning outcomes (Knowles, 1975). Indirectly, the self-directed learning allows an ample room for students to plan, adapt and evaluate their own learning. Number of studies has exemplified that students were still struggling to utilize the self-directed learning in PBL (Malan, Ndlovu, \& Engelbrecht, 2014).

A study by Yew and Schmidt (2009) found students' mastery level in evaluating resources was poor. This might due to the fact that the students were still affected by the conventional teaching practices, where the learning resources were mostly provided by their teachers. The students might struggle to evaluate and select reliable and valid resources. However, the blended PBL offers an alternative to this condition, where the teacher can constantly facilitating students in the form of scaffolding during material selections. In self-directed learning, scaffolding will be decreased over the time, depending on their needs and ability to perform the tasks independently. For instance, teachers can provide links on the learning platform in guiding students and conditioning them to the concept of PBL. Students, on the other hand, are free to choose the information based on the suggested links. This autonomy is seen to be relevant to the concept of self-directed learning in PBL (Wijnia et al., 2014).

In addition, the concept of scaffolding allows students to plan their learning. Yew and Schmidt (2009) supported that planning their own learning is important and can be developed in PBL. This learning skill is relevant in helping students to design their learning strategies in realizing the learning objectives. In doing so, the teachers can simply provide graphic organizers in the form of worksheet on the online platform in guiding them to organize and evaluate the gathered information systematically (Choo, 2012). The teachers are also encouraged to prompt questions online based on the learning strategies and planning for fostering students to reflect and evaluate their learning (Yew \& Schmidt, 2009).

\section{Conclusion}

In conclusion, the proposed blended PBL framework is potentially effective in dealing with drawbacks and challenges of collaborative and self-directed learning settings. The integration of online learning platform and face-to-face learning offers an ideal alternative to achieve deep learning and thus, improves the mastery of HOTS. It is hoped that the implementation of blended PBL helps to prepare and shape the current teaching and learning settings to cater the needs of $21^{\text {st }}$ century learning.

\section{Acknowledgements}

The author would like to thanks the Universiti Teknologi Malaysia (UTM) and Ministry of Education (MOE) Malaysia for their support in making this project possible. This work was supported by the Potential Academic 
Staff grant (Q.J130000.2731.00K81) initiated by UTM and MOE.

\section{References}

Alias, M., \& Saleh, H. H. M. (2007). The effect of the blended Problem-Based Learning method on the acquisition of content-specific knowledge in mechanical engineering. World Transaction on Engineering and Technology Education, 6(2), 249-252.

An, Y. (2013). Systematic Design of Blended PBL: Exploring the Design Experiences and Support Needs of PBL Novices in an Online Environment. Contemporary Issues in Technology and Teacher Education, 13(1), 61-79.

Avargil, S., Herscovitz, O., \& Dori, Y. J. (2013). Challenges in the transition to large-scale reform in chemical education. Thinking Skills and Creativity, 10, 189-207. http://dx.doi.org/10.1016/j.tsc.2013.07.008

Barak, M., \& Dori, Y. J. (2009). Enhancing Higher Order Thinking Skills Among Inservice Science Teachers Via Embedded Assessment. Journal of Science Teacher Education, 20(5), 459-474. http://dx.doi.org/10.1007/s10972-009-9141-z

Brownell, J. (2004). Problem-Based Learning in Graduate Management Education: An Integrative Model and Interdisciplinary Application. Journal of Management Education, 28(5), 558-577. http://dx.doi.org/10.1177/1052562904266073

Carbonell, K. B., Dailey-hebert, A., Gerken, M., \& Grohnert, T. (2013). Problem-Based Learning in Hybrid, Blended or Online Courses: Instructional and Change Management Implication For Supporting Learner Enggagement. Cutting-Edge Technologies in Higher Education, 6, 359-386. http://dx.doi.org/10.1108/S2044-9968(2013)000006G015

Choi, E., Lindquist, R., \& Song, Y. (2014). Nurse Education Today Effects of problem-based learning vs. traditional lecture on Korean nursing students' critical thinking, problem-solving, and self-directed learning. YNEDT, 34(1), 52-56. http://dx.doi.org/10.1016/j.nedt.2013.02.012

Choo, S. S. Y. (2012). One-Day, One-Problem. In G. O’Grady, E. H. J. Yew, K. P. L. Goh, \& H. G. Schmidt (Eds. pp. 167-184). Singapore: Springer Singapore. http://dx.doi.org/10.1007/978-981-4021-75-3

Davies, J., de Graaff, E., \& Eds, A. K. (2011). Implementing Problem Based Learning In Materials Science. In J. Davies, E. de Graaff, \& A. Kolmos (Eds.), PBL across the disciplines: Research into best practice (pp. 222-233). Aalborg University Press.

Delialioglu, O., \& Yildirim, Z. (2007). Students 'Perceptions on Effective Dimensions of Interactive Learning in a Blended Learning Environment. Education Technology \& Society, 10(2), 133-146.

Dolmans, D. H. J. M., Wolfhagen, I. H. A. P., Van Der Vleuten, C. P. M., \& Wijnen, W. H. F. W. (2001). Solving problems with group work in problem-based learning: Hold on to the philosophy. Medical Education, 35, 884-889.

Donnelly, R. (2013). The role of the PBL tutor within blended academic development. Innovations in Education and Teaching International, 50(2), 133-143. http://dx.doi.org/10.1080/14703297.2012.760866

Dwyer, C. P., Hogan, M. J., \& Stewart, I. (2014). An integrated critical thinking framework for the 21 st century. Thinking Skills and Creativity, 12, 43-52. http://dx.doi.org/10.1016/j.tsc.2013.12.004

Hmelo-Silver, C. E. (2004). Problem-Based Learning: What and How Do Students Learn? Educational Psychology Review, 16(3), 235-266. http://dx.doi.org/10.1023/B:EDPR.0000034022.16470.f3

Hung, W. (2009). The 9-step problem design process for problem-based learning: Application of the 3C3R model. Educational Research Review, 4(2), 118-141. http://dx.doi.org/10.1016/j.edurev.2008.12.001

Hung, W. (2011). Theory to reality: A few issues in implementing problem-based learning. Education Tech Research Dev, 59, 529-552. http://dx.doi.org/10.1007/s11423-011-9198-1

Kashefi, H., Zaleha, I., \& Yudariah, M. Y. (2012). The Impact of Blended Learning on Communication Skills and Teamwork of Engineering Students in Multivariable Calculus. Procedia-Social and Behavioral Sciences, 56(Ictlhe), 341-347. http://dx.doi.org/10.1016/j.sbspro.2012.09.662

Kiong, T., Heong, M., \& Jailani. (2010). The Level of Higher Order Thinking Skills for Technical Subject in Malaysia. In Proceedings of the 1st UPI International Conference on Techinical and Vocational Education and Training Bandung, Indonesia (pp. 82-90). Bali, Indonesia.

Kirschner, P. A., Sweller, J., \& Clark, R. E. (2006). Why Minimal Guidance During Instruction Does Not Work: 
An Analysis of the Failure of Constructivist, Based Teaching Work: An Analysis of the Failure of Constructivist, Discovery, Problem-Based, Experiential, and Inquiry-Based Teaching. Educational Physhologist, 41(2), 75-86. http://dx.doi.org/10.1207/s15326985ep4102

Knowles, M. S. (1975). Self-directed Learning. A guide for leaners and teachers (p. 18). New York: Association Press.

Koh, G. C.-H., Khoo, H. E., Wong, M. L., \& Koh, D. (2008). The effects of problem-based learning during medical school on physician competency: A systematic review. Canadian Medical Association Journal, 178(1), 34-41.

Krathwohl, D. R. (2002). A Revision of Bloom's Taxonomy: An Overview. Theory Into Practice, 41(4), 212-218. http://dx.doi.org/10.1207/s15430421tip4104

Lam, C. C., Alviar-Martin, T., Adler, S. A., \& Sim, J. B.-Y. (2013). Curriculum integration in Singapore: Teachers' perspectives and practice. Teaching and Teacher Education, 31, 23-34. http://dx.doi.org/10.1016/j.tate.2012.11.004

Lau, N., Lam, L., \& Zhou, B. (2010). Enhancing Blended Courses to Facilitate Student Achievement of Learning Outcomes. In P. Tsang et al. (Eds.), Hybrid Learning, Third International Conference, ICHL 2010, Beijing, China, August 2010, Proceedings (pp. 205-216). Springer-Verlag Berlin Heidelberg 2010.

Lewis, A., \& Smith, D. (1993). Defining Higher Order. Teaching for Higher Order Thinking (Summer, 1993), 32(3), 131-137.

Malan, S. B., Ndlovu, M., \& Engelbrecht, P. (2014). Introducing problem-based learning (PBL) into a foundation programme to develop self-directed learning skills. South African Journal of Education, 34(1), 1-16.

Malaysian Examination Syndicate. (2013). Pentaksiran Kemahiran Berfikir Aras Tinggi (p. 36). Putrajaya.

Martin, M. O., Mullis, I. V. S., Foy, P., \& Stanco, G. M. (2011). TIMSS 2011 International Result in Science. North Andover, MA: Flagship Press.

Mccall, I. (2010). Online enhanced problem-based learning: assessing a blended learning framework. The Law Teacher, 44(1), 42-58. http://dx.doi.org/10.1080/03069400903541336

Ministry of Education Malaysia. (2012). Pelan Pembangunan Pendidikan Malaysia (2013-2025) (p. 19). Putrajaya.

Mohd, N. H. M. S., Johari, H. B., Abdul-Razak, I., Megat, A. Z., \& Forret, M. C. E. (2013). Technology-enhanced Classroom Learning Community for Promoting Tertiary ICT Education Learning in Malaysia. The 4th International Research Symposium on Problem-Based Learning (IRSPBL) 2013, 326-333.

Nargundkar, S., Samaddar, S., \& Mukhopadhyay, S. (2014). A Guided Problem-Based Learning (PBL) Approach: Impact on Critical Thinking. Decision Sciences Journal of Innovative Education, 12(2), 91-108. http://dx.doi.org/10.1111/dsji.12030

Nor-Fardia, H., Khairiyah, M. Y., Muhammad, Z. J., \& Syed, A. H. S. H. (2012). Motivation in Problem-based Learning Implementation. Procedia - Social and Behavioral Sciences, 56(Ictlhe), 233-242. $\mathrm{http}: / / \mathrm{dx}$. doi.org/10.1016/j.sbspro.2012.09.650

OECD. (2014). PISA 2012 Results: What Students Know and Can Do-Student Performance in Mathematics, Reading and Science (Vol. I). http://dx.doi.org.org/10.1787/9789264208780-en

Oliver, K. M., \& Stallings, D. T. (2014). Preparing Teachers for Emerging Blended Learning Environments. Journal of Technology and Teacher Education, 22(1), 57-81.

Onwuegbuzie, A. J., Leech, N. L., \& Collins, K. M. T. (2012). Qualitative Analysis Techniques for the Review of the Literature. The Qualitative Report 2012, 17(56), 1-28.

Qiu, M., \& McDougall, D. (2013). Foster strengths and circumvent weaknesses: Advantages and disadvantages of online versus face-to-face subgroup discourse. Computers \& Education, 67, 1-11. http://dx.doi.org/10.1016/j.compedu.2013.02.005

Ramli, M., \& Zaharatul, L. (2011). Problem-Based Learning in Malaysian Technical School. International Journal for Educational Studies, 4(1), 41-54.

Resnick, L. B. (1987). Education and Learning to Think (1st printi., pp. 1-73). Washington: National Academy Press2101. Retrieved from http://www.nap.edu/catalog/1032.html 
Rissi, J. R. (2010). Efficacy of Problem Based Learning in A High School Science Classroom. Michigan State University.

Savin-baden, Maggi, C. H. M. (2004). Foundations of Problem Learning (1st ed., pp. 4-5). New York, NY: Open University Press.

Sellar, S., \& Lingard, B. (2013). Looking East: Shanghai, PISA 2009 and the reconstitution of reference societies in the global education policy field. Comparative Education, 49(4), 464-485. http://dx.doi.org/10.1080/03050068.2013.770943

Shukor, N. A., Tasir, Z., Zaid, N., \& Ahmad, N. (2014). The Design of a Computer-Supported Collaborative Learning Environment that Promotes Interaction. In Teaching and Learning Environment in Computing and Engineering (LaTiCE), 2014 International Conference on (pp.47-51). IEEE.

Strauss, A., \& Corbin, J. (1998). Basics of qualitative research: Techniques and procedures for developing grounded theory. Thousand Oaks, CA: Sage.

Tan, C. (2014). Beyond Rote-Memorisation: Confucius' Concept of Thinking. Educational Philosophy and Theory, (July), 1-12. http://dx.doi.org/10.1080/00131857.2013.879693

Tan, Y. P., \& Muhammad, Y. (2013). FILA-MMS Chart in Chemistry PBL Lesson: A Case Study of Its Implementation During Problem Analysis.

Taylor, P., Francis, R., \& Shannon, S. J. (2013). Engaging with blended learning to improve students' learning outcomes. European Journal of Engineering Education, 3013, 38(4), 37-41. http://dx.doi.org/10.1080/03043797.2013.766679

Vardi, I., \& Ciccarelli, M. (2008). Overcoming problems in problem-based learning: A trial of strategies in an undergraduate unit. Innovations in Education and Teaching International, 45(4), 345-354. http://dx.doi.org/10.1080/14703290802377190

Vijayaratnam, P. (2012). Developing Higher Order Thinking Skills and Team Commitment via Group Problem Solving: A Bridge to the Real World. Procedia-Social and Behavioral Sciences, 66, 53-63. http://dx.doi.org/10.1016/j.sbspro.2012.11.247

Wijnia, L., Loyens, S. M. M., Derous, E., \& Schmidt, H. G. (2014). How important are student-selected versus instructor-selected literature resources for students' learning and motivation in problem-based learning? Instructional Science. http://dx.doi.org/10.1007/s11251-014-9325-6

Wirkala, C., \& Kuhn, D. (2011). Problem-Based Learning in K-12 Education: Is it Effective and How Does it Achieve its Effects? American Educational Research Journal, 48(5), 1157-1186. http://dx.doi.org/10.3102/0002831211419491

Woltering, V., Herrler, A., Spitzer, K., \& Spreckelsen, C. (2009). Blended learning positively affects students' satisfaction and the role of the tutor in the problem-based learning process: Results of a mixed-method evaluation. Advances in Health Sciences Education: Theory and Practice, 14(5), 725-38. http://dx.doi.org/10.1007/s10459-009-9154-6

Yeung, S. (2010). Problem-Based Learning for Promoting Student Learning in High School Geography. Journal of Geography, 109(5), 190-200. http://dx.doi.org/10.1080/00221341.2010.501112

Yew, E. H. J., \& Schmidt, H. G. (2009). Evidence for constructive, self-regulatory, and collaborative process in problem-based learning. $A d v$ in Health Sci Educ, (14), 251-273. http://dx.doi.org/10.1007/s10459-008-9105-7

Yew, E. H. J., \& Schmidt, H. G. (2011). What students learn in problem-based learning: A process analysis. Instructional Science, 40(2), 371-395. http://dx.doi.org/10.1007/s11251-011-9181-6

\section{Copyrights}

Copyright for this article is retained by the author(s), with first publication rights granted to the journal.

This is an open-access article distributed under the terms and conditions of the Creative Commons Attribution license (http://creativecommons.org/licenses/by/3.0/). 